\title{
Rejecting Absolute Immunity for Federal Officials
}

The traditional doctrine of sovereign immunity prevents a private person from suing the United States Government for damages resulting froin a violation of her constitutional rights. ${ }^{1}$ Similarly, the Federal Torts Claims Act (FTCA), which partially waives United States sovereign immumity, does not permit damage claims against the Governinent based directly on the Constitution. ${ }^{2}$ However, under a line of Supreme Court cases beginning with Bivens v. Six Unknown Named Agents of Federal Bureau of Narcotics ${ }^{3}$ in 1971, there is a private right of action against individual officials for their alleged violations of constitutional guarantees. ${ }^{4}$

The sentiment is widespread that the current system, which holds federal officials individually accountable for constitutional violations and imsulates the Government itself, is rife with problems ${ }^{s}$ Critics of the current system argue that the threat of litigation and personal liability hinders employees in assertively executing their duties. ${ }^{6}$ They also argue that the current system for vindicating constitutional rights is ineffective because it is very difficult for aggrieved plaintiffs to recover damages in Bivens actions. ${ }^{7}$

In response to these problems, Congress and the executive branch have developed various proposals over the past ten years to annend the FTCA and lift the sovereign immunity bar to damage actions directed

I. "It is now well settled-although for a century the rule was stated only in dicta-that the United States may not be sued without its consent. The absence of consent is a fundamental, jurisdictional defect . . . " 14 C. Wright, A. Miller \& E. Cooper, Federal Practice AND ProcedURe: JURISDiction $§ 3654$ (1976 \& Supp. 1983) (footnotes omitted). The United States has not consented to be sued for constitutional violations. See id. $\$ \S 3656-3658$.

2. 28 U.S.C. $\$ \S 1346(b), 2671-2680$ (1976 \& Supp. V 1981).

3. 403 U.S. 388 (1971).

4. See Carlson v. Green, 446 U.S. 14 (1980) (eighth amendment); Davis v. Passman, 442 U.S. 228 (1979) (fifth amendment); infra notes 33-38.

5. For criticisn and detailed analysis of the problems under the current system, see 125 Cong. REC. 5274-75 (1979) (statenient of Sen. Keunedy); Schuck, Suing our Servants: The Court, Congress, and the Liability of Public Officials for Damages, 1980 SuP. CT. Rev. 281; Note, "Damages or Nothing"- The Efficacy of the Bivens-Type Remedy, 64 CORNELL L. REv. 667 (1979).

6. Federal Tort Claims Act: Hearings on S. 1775 Before the Subcomm. on Agency Administration of the Senate Comm. on the Judiciary, 97th Cong., 1st \& 2d Sess. pt. 2, at 133 (1982) (statenent of Elliot L. Richardson, former U.S. Att'y Gen.) [hereinafter cited as $S .1775$ Hearings].

7. See Federal Tort Claims Act: Hearings on H.R. 9219 Before the Subcomm. on Administrative Law and Governmental Relations of the House Comm. on the Judiciary, 95th Cong., 2d Sess. 74 (statement of Barbarba Allen Babcock, Assistant Att'y Gen.) [hereinafter cited as H.R. 9219 Hearings]; accord S. 1775 Hearings, supra note 6, pt. 2, at 160-61 (statement of J. Paul McGrath, Assistant Att'y Gen.). 
against the federal Government for constitutional violations. ${ }^{8}$ Most of these proposals suggest that the federal Government be the sole defendant in actions brought for constitutional violations, and that all federal officials be granted absolute immunity. Although absolute immunity proposals have gained substantial bipartisan support, ${ }^{10}$ none has been enacted.

This Comment focuses on the probleins presented by absolute immunity, and proposes certain anendments to the FTCA. While other proposed FTCA amendments correctly make the Government a party to actions involving constitutional violations, they inappropriately shield officials from hability for malicious or reckless violations. Admittedly such extensive immunity safeguards employees from harassing hitigation, but absolute immunity does not adequately protect individuals because it does not encourage official accountability or deter wrongdoing. This Comment argues that recent changes in the law of official immunity, which make it easier for officials to get dismissals and summary judgments, provide adequate safeguards for employees while maintaining deterrence and accountability.

This Comment also argues that when an individual proves that her constitutional rights were violated, the Government should compensate her for that injury. If the injury resulted from an action the employee knew or should have known violated an individual's constitutional rights, the Government should have a right of contribution against the einployee for any coinpensatory damages awarded; and, if the official's actions were malicious or reckless, she should be solely liable for any. punitive damages awarded. However, when the outrageous behavior justifying punitive damages stems in part from a policy or practice actively encouraged by an agency, and not solely attributable to the official who performed the act, the court should have discretion to assess punitive damages against both the official and the Government.

Part I of this Comment surveys and discusses the current law that partially shields the federal Government and federal officials from hability for constitutional violations. Part II presents the inajor reasons why the Government should waive sovereign immumity, and Part III

8. See, e.g., H.R. 595, 98th Cong., 1st Sess. (1983); S. 775, 98th Cong., 1st. Sess. (1983); H.R. 7034, 97th Cong., 2d Sess. (1982); H.R. 24, 97th Cong., 1st Sess. (1981); S. 1775, 97th Cong., 1st Sess. (1981); S. 695, 96th Cong., 1st Sess. (1979); H.R. 2659, 96th Cong., 1st Sess. (1979); S. 2117, 95th Cong., 1st Sess. (1977); H.R. 9219, 95th Cong., 1st Sess. (1977); H.R. 10439, 93d Cong., 1st Sess. (1973); S. 2558, 93d Cong., 1st Sess. (1973).

9. Bell, Proposed Amendments to the Federal Tort Clainis Act, 16 HARv. J. ON LEOIs. 1, 10 (1979); Casto, Government Liability for Constitutional Torts: Proposals 10 Amend the Federal Tort Claims ACt, 49 TENN. L. REv. 201, 209 (1982).

10. See Casto, supra note 9, at 208-09; Madden, Allard \& Remes, Bedtime for Bivens: Sub. stituting the United States as Defendant in Constitutional Tort Sutis, 20 HARV. J. ON LEGIs. 469, 478 (1983). 
discusses the continumg need for some form of individual liability when federal officials violate the constitutional rights of citizens. Part IV examines the shortcomings of certain alternatives to individual liability in damage actions. Finally, Part V discusses a proposal to ainend the FTCA that reconciles the need to protect federal officials from costly litigation and the need to deter thein from willful constitutional violations.

\section{I}

\section{CurRent LaW}

\section{A. Liability of the Federal Government for Constitutional Violations}

The sovereign immunity doctrime bars all claims against the United States Government, ${ }^{11}$ including those based on constitutional violations. ${ }^{12}$ This doctrime, which developed froin the English cominon law primciple that "the King can do no wrong," 13 prohibits damages actions against the federal Government unless it consents to suit. However, gradual recognition that the doctrime was often unjust and impractical led Congress, beginning in the nineteenth century, to pass legislation waiving sovereign immunity and consenting to suit in certain areas. ${ }^{14}$

In 1946, Congress passed the FTCA, ${ }^{15}$ which removed the sovereign immunity bar to suits against the federal Government for the negligent acts of its employees in circumstances under which a private person would be liable. In 1974, the FTCA was amended to allow suits against the federal Government for the intentional torts of its investigative or law enforcement officials, including assault, battery, false im-

11. See United States v. Mitchell, 445 U.S. 535, 538 (1980); Cohens v. Virginia, 19 U.S. (6 Wheat.) $264,411-12$ (1821).

12. See Note, supra note 5 , at 669.

13. See Commissioners of the State Ins. Fund v. United States, 72 F. Supp. 549, 552 (S.D.N.Y. 1947) (discussing the English common law origins of the sovereign immunity doctrine).

14. In 1855 the Court of Claims was established to hear most types of monetary claims other than tort claims against the federal Government. Act of Feb. 24, 1885, ch. 122, 10 Stat. 612 (codified as amended at 28 U.S.C. $\$ 171$ (1976)). In 1887 the Tucker Act was enacted granting jurisdiction for contractual claims against the Government. Act of Mar. 3, 1887, ch. 359, 24 Stat. 505 (codified as ainended at 28 U.S.C. § 1346(a)(2), 1491 (1976 \& Supp. V 1981)).

15. Federal Tort Claims Act, ch. 753, tit. IV, 60 Stat. 812, 842-47 (1946) (codified as amended in scattered sections of 28 U.S.C. (1976)). The current version of the Act provides that

the district courts . . . shall have exclusive jurisdiction of civil actions on claims against the United States, for money damages, accruing on and after January 1, 1945, for injury or loss of property, or personal injury or death caused by the negligent or wrongful act or omission of any einployee of the Government while acting within the scope of his office or einployment, under circunstances where the United States, if a private person, would be liable to the claimant in accordance with the law of the place where the act or omission occurred.

28 U.S.C. \& 1346(b) (1976). 
prisonment, false arrest, abuse of process, and malicious prosecution. ${ }^{16}$ The FTCA precludes governmental liability for damages caused by certain government functions, mcluding the operation of the treasury and regulation of the inonetary system, wartime military operations, transmission of letters or other postal matter, and the exercise of "discretionary" functions or duties. ${ }^{17}$

Under the FTCA, a claimant inust demonstrate that the action taken by a government employee was within the "scope of office or employment."18 Courts have interpreted this requirement to include willful torts committed either with an intent to further the Government's interest or where the use of force was foreseeable in the type of employment involved. ${ }^{19}$ For example, in Avery v. United States ${ }^{20}$ a federal district court found that CIA agents who illegally opened the mail of private citizens acted within the scope of their employment because their conduct was motivated by a desire to serve governmental rather than personal ends. ${ }^{21}$

Although no cause of action exists against the federal Government for violating a constitutional right, ${ }^{22}$ such a claim is actionable under the FTCA if it can be framed as a negligent or intentional tort under the terms of the law of the state where the act occurred. ${ }^{23}$ For example, in Birnbaum v. United States, ${ }^{24}$ the plaimtiff sued the Government under the FTCA to recover damages for the CIA's illegal interception, opening, and copying of his mail without a warrant or probable cause. Although the plaintiff could not rest his claim on the violation of his first and fourtli amendment rights, his claim was allowed because New York's common law permits a cause of action for invasion of privacy and violations of the United States Constitution by government agents. ${ }^{25}$ In contrast, in Brown $v$. United States ${ }^{26}$ a Texas plaintiff sued the United States, alleging that a government official's false testimony led to his arrest without probable cause and thereby violated his fourth and fifth anendment rights. ${ }^{27}$ The Fifth Circuit dismissed the claim, holding that the action could not be maintained because the law of

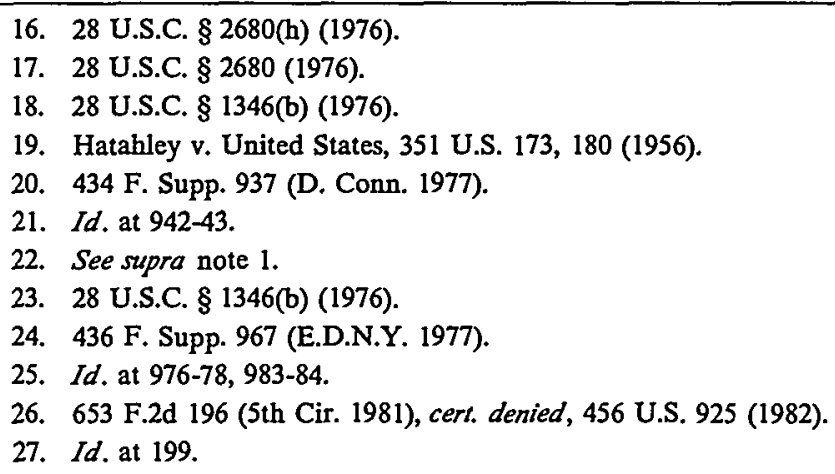


Texas would not support it. ${ }^{28}$

\section{B. Liability of Federal Officials for Constitutional Violations}

A cause of action for damages based directly on the Constitution inay, however, be brought against the responsible federal official. The Supreine Court created this cause of action in Bivens v. Six Unknown Named Agents of Federal Bureau of Narcotics, ${ }^{29}$ where the plaintiff Bivens alleged that federal narcotics agents had violated his fourth ainendment rights by entering his house, searching it, and arresting him without a warrant or probable cause and using unreasonable force.

In Bivens the Court stated that although the fourth amendment does not explicitly provide for an award of nonetary dainages, "it is . . . well settled that where legal rights have been invaded, and a federal statute provides for a general right to sue for such invasion, federal courts may use any available remedy to make good the wrong done."30 Justice Harlan explained in his concurring opinion that the Court authorized monetary damages because no alternative remedy was available:

[S]ome form of damages is the only possible remedy for someone in Bivens' alleged position. It will be a rare case indeed in which an individual in Bivens' position will be able to obviate the harm by securing injunctive relief from any court. . . . [A]ssuming Bivens' innocence of the crime charged, the "exclusionary rule" is simply irrelevant. For people in Bivens' shoes, it is damages or nothing. ${ }^{31}$

Unlike an FTCA action agamst the federal Government, a Bivens action against individual federal officials arising from a constitutional violation is not confined by the limits of state tort law. The Bivens Court stated that since the fourth amendment limits federal power, the determination that an act violates the fourth amendment does not depend on whether the state where the power was exercised would prohibit or penalize the saine act by a private citizen. ${ }^{32}$

Although some courts have held that a Bivens action may be

28. Id. at 201; accord Barlow v. Avco Corp., 527 F. Supp. 269, 272-73 (E.D. Va. 1981); Davis v. United States, 395 F. Supp. 793, $795-97$ (D. Neb. 1975), affd per curiam, 536 F.2d 758, 759 (8th Cir. 1976).

Recent proposals to amend the FTCA suggest eliminating the current requirement that claims under the Act be framed in accordance with state law. These proposals would waive sovereign immunity for torts "arising under the Constitution of the United States." See, e.g. H.R. 7034, 97th Cong., 2d Sess. $\$ 202$ (1982) (proposed 28 U.S.C. $\$ 2691$ ); S. 1775, 97th Cong., 1st Sess. $\S 2$ (1981) ("such liability to be determined in accordance with apphicable Federal law").

29. 403 U.S. 388 (1971).

30. Id. at 396 (quoting Bell v. Hood, 327 U.S. 678, 684 (1946)).

31. Id. at 409-10.

32. Id. at 392 . 
brought only for fourth amendment violations, ${ }^{33}$ recent Supreme Court decisions have extended the cause of action to violations of other constitutional rights. For example, in Davis v. Passman, ${ }^{34}$ a woman sued a United States Congressman for wrongfully terminating her employment, alleging discrimination on the basis of sex im violation of the due process clause. ${ }^{35}$ The Court held that when an official violates the due process clause of the fifth amendment, the Constitution itself implies a cause of action and a damages remedy. ${ }^{36}$ And in Carlson v. Green, ${ }^{37}$ the Court recognized a cause of action based on a violation of the eighth amendment where the plamtiff sought damages from federal prison officials for injuries that resulted in the death of her son. ${ }^{38}$

\section{Limits on Individual Liability}

\section{Equally Effective Alternative-A Limit on the Bivens Action}

In developing the Bivens-Passman-Carlson line of cases, the Supreme Court has limited this cause of action to situations in which "Congress has [not] provided an alternative remedy which it explicitly declared to be a substitute for recovery directly under the Constitution and viewed as equally effective." 39 In Carlson the Court recognized that the remedy available against the Government under the FTCA is not as effective as that provided against individual officials under $B i v$ ens. For this reason the Court found that the FTCA does not provide the sole reniedy. Instead, it creates a parallel, complementary cause of action to that established by Bivens. ${ }^{40}$ It is clear from Carlson, how-

33. See, e.g., Moore v. Schlesinger, 384 F. Supp. 163, 165 (D. Colo. 1974). For a history of the development of the Bivens cause of action, see Project, Constitutional Torts Ten Years Affer Bivens, 9 Hofstra L. REv. 943, 1004-18 (1981).

34. 442 U.S. 228 (1979).

35. Id. at 231.

36. Id. at 242 .

37. 446 U.S. 14 (1980).

38. Respondent alleged specifically that prison officials, against medical advice, refused to transfer her son to an outside hospital until nearly eight hours after he suffered a serious asthma attack. She maintained that her son received incoinpetent medical care, that he was given contraindicated drugs that made the attack more severe, and that he was treated with a respirator that was not functioning properly and further impeded his breathing. Id. at 16 n.1.

39. Carlson, 446 U.S. at 18-19 (emphasis in original) (citing Bivens, 403 U.S. at 397). The Court also stated that a Bivens action would only be available where there are "no special factors counselling hesitation in the absence of affirmative action by Congress." Bivens, 403 U.S. at 396; see also Carlson, 446 U.S. at 18; Passman, 442 U.S. at 245. Such "special factors" existed in Bush v. Lucas, 103 S. Ct. 2404 (1983), where there was an elaborate statutory scheme. The Court refused to create a Bivens remedy even though the statutory remedy was less effective than a private damages action. $I d$. at 2408, 2414-16.

40. Carlson, 446 U.S. at 18-19 (citing Bivens, 403 U.S. at 397, and Passman, 442 U.S. at 245. 47). The Court cites four reasons why the Bivens remedy is more effective than the FTCA: (1) because Bivens provides individual hability, it deters official misconduct nore effeetively than does the FTCA remedy against the United States; (2) punitive damages are allowed in Bivens actions but not under the FTCA; (3) the right to jury trial exists under Bivens but not under the 
ever, that the development of an equally effective remedy will defeat a plamtiff's efforts to sue an official individually.

\section{Official Immunity}

The judicially created law of official immunity limits the ability of a Bivens plaimtiff to recover damages from an official. An official can assert two types of immunity as defenses to a constitutional violation: "good faith" or "qualified" immunity, 41 and "absolute" immunity" based on the "function" the federal official is performing. An official who successfully asserts either of these immunities will defeat a claim for damages even if it is established that her actions violated a person's constitutional rights.

\section{a. Qualified Immunity}

In Butz v. Economou, ${ }^{43}$ the Supreme Court estabhishcd immunity for federal officials who act in good faith. ${ }^{44}$ The Court reasoned that the rationales it had used in Scheuer $v$. Rhodes ${ }^{45}$ to establish qualified immunity for state officials in suits brought under 42 U.S.C. $\$ 1983$ were equally applicable to federal officials sued for constitutional violations. ${ }^{46}$ In Scheuer the Court emphasized the injustice, particularly in the absence of bad faith, of imposmg liability on an officer whose position requires her to exercise discrction. The Court also stated that the threat of liability might decrease the official's willingness to execute her duties "with the decisivenesss and the judgment required by the public good."

Until recently, the availability of qualified immunity turned on a standard that was in part subjective. The standard that applied to federal officials was identical to the Wood $\nu$. Strickland ${ }^{48}$ standard applicable to state officials in section 1983 actions. This two-pronged test asked whether the official knew or reasonably should have known that her action would violate the plaintiff's constitutional rights, and

FTCA; and (4) under the FTCA, a cause of action exists only if it is recognized under law of the place where the act occurred. Bivens actions arise under the Constitution and thus hability for federal officials is governed by federal law. Id. at 19-23.

41. See infra notes $43-56$ and accompanying text.

42. See infra notes $57-68$ and accompanying text.

43. 438 U.S. 478 (1978). The plaintiff sued Department of Agriculture officials for violating his constitutional rights by instituting unauthorized proceedings against him in retaliation for his criticism of the department.

44. Id. at 507 .

45. 416 U.S. 232 (1974).

46. 42 U.S.C. $\$ 1983(1976)$ is the federal statute that provides a cause of action for constitutional violations committed under color of state law.

47. Scheuer v. Rhodes, 416 U.S. 232, 240 (1974).

48. 420 U.S. 308 (1975). 
whether the official took such actions with malicious intent. ${ }^{49}$

To apply this test, a court had to examine an official's thought processes. This inquiry necessarily raised a question of fact, making summary judgment difficult to obtain. ${ }^{50}$ Thus, a full-scale trial would often be required before an official could be adjudged immune froin hability for a constitutional violation. Commentators criticized the Wood test, arguing that time-consuming and costly suits placed a lieavy burden on government officials. ${ }^{51}$

In 1982 the Supreme Court changed the qualified immunity test to a single objective standard inore suitable for summary judgment. In Harlow v. Fitzgerald, ${ }^{52}$ the plaintiff sought damages for violations of his constitutional rights, alleging that federal officials and senior aides to President Nixon conspired to terminate his employment for planning to "blow the whistle" on Defense Department cost overruns and questionable purchasing practices. ${ }^{53}$ The Court acknowledged that the Wood test was inconsistent with the Court's admonition in Butz that insubstantial claims against federal officials should not proceed to trial. ${ }^{54}$ In an effort to make the qualified immunity issue more appropriate for summary judgment, the Harlow Court held that "government officials performing discretionary functions generally are shielded from liability for civil damages insofar as their conduct does not violate clearly established statutory or constitutional rights of which a reasonable person would have known."5s The Court reasoned that with this objective test the question of immunity could be resolved at the outset of a trial, thereby reducing the lengthy litigation cominon in Bivens actions. $^{56}$

\section{b. Absolute Immunity}

Absolute immunity ${ }^{57}$ is granted when a government official performs a "special function" that requires complete protection from hability." As the Court stated in Butz," "fo "federal officials who seek

49. Id. at 322 .

50. Rule 56 of the Federal Rules of Civil Procedure provides that a motion for summary judgment ordinarily may not be granted where there are disputed questions of fact. FED. R. CIv. P. 56.

51. See Harlow v. Fitzgerald, 457 U.S. 800, 815-16 (1982); Schuck, supra note 5, at 330.

52. 457 U.S. 800 (1982).

53. Id. at 804 .

54. Id. at 815-16.

55. Id. at 818 .

56. However, as Justice Brennan poimted out in his concurring opinion, discovery will sometimes be required to determine exactly what a public official knew at the time he acted. Id. at 821 (Brennan, J., concurring).

57. See, e.g. , Spalding v. Vilas, 161 U.S. 483, 498 (1896).

58. Nixon v. Fitzgerald, 457 U.S. 731,747 (1982).

59. 438 U.S. 478 (1978). 
absolute exemption from personal liability for unconstitutional conduct must bear the burden of showing that public policy requires an exemption of that scope." ${ }^{60}$ To date legislative, ${ }^{61}$ judicial, ${ }^{62}$ prosecutorial, ${ }^{63}$ and, most recently, presidential ${ }^{64}$ functions have been afforded absolute immunity. ${ }^{65}$

Absolute immunity depends on the function that is being performed rather than on the defendant's status or job title: "An executive official's claim to absolute immunity nust be justified by reference to the public interest in the special functions of his office, not the nere fact of high station." 66 For example, in Supreme Court $v$. Consumers Union, ${ }^{67}$ the Court held that the judges of the Supreme Court of Virginia possessed absolute immunity not because they were judges, but because they were bemg sued for actions of a legislative nature and, as such, were immune from dainage actions to the extent they performed a legislative function. ${ }^{68}$

II

WAIVER OF THE SOVEREIGN IMMUNITY BAR TO COMPENSATION

There is widespread support for proposals to waive sovereign immunity in order to allow victims of constitutional violations to recover directly froin the Government. ${ }^{69}$ Since 1973, each administration has proposed such a waiver. ${ }^{70}$ Congress too has recognized the need to amend the FTCA, with its debates focusing on the design of the waiver. ${ }^{71}$ Commentators have also generally endorsed a waiver of sov-

60. Id. at 506.

61. Eastland v. United States Servicenien's Fund, 421 U.S. 491 (1975) (speech or debate clause, U.S. ConST. art. I, $\$ 6$, cl. 1, shields legislators).

62. Pierson v. Ray, 386 U.S. 547, 554 (1967); Bradley v. Fisher, 80 U.S. (13 Wall.) 335 (1871).

63. Imbler v. Pachtman, 424 U.S. 409 (1976).

64. Nixon v. Fitzgerald, 457 U.S. 731 (1982).

65. Pierson and Imbler establish absolute immunity for state officials sued under 42 U.S.C. $\S 1983$. However, according to the Butz Court, without Congressional directives to the contrary it is untenable to draw distinctions in immunity law between suits against state officials in $\$ 1983$ cases and suits against federal officials in a Bivens action. 438 U.S. 478, 504 (1978).

66. Harlow v. Fitzgerald, 457 U.S. 800, 812 (1982).

67. 446 U.S. 719 (1980).

68. Id. at 731-33. The Virginia Supreme Court acted in its legislative capacity when it pronulgated the Virginia Code of Professional Responsibililty and organized the Virginia Bar as an adminstrative agency to investigate and report violations of the Code. Id. at 721-22.

69. See supra note 10.

70. See supra note 8 . In 1974, Congress passed an amendment to allow suits against the United States under the FTCA for certain intentional torts. See Boger, Gitenstein \& Verkuil, The Federal Tort Claims Act Intentional Torts Amendment: An Interpretative Analysis, 54 N.C.L. Rev. 497 (1976).

71. See generally Federal Tort Claims: Hearings on H.R. 595 Before the Subcomm. on Administrative Law and Governmental Relations of the House Comm. on the Judiciary, 98th Cong., 1st 
ereign immunity for constitutional violations. ${ }^{72}$ There are two key reasons for the strong and broad-based support for a waiver of sovereign immunity: increasing victim compensation and limiting employee liability to ensure assertive decisionmaking.

\section{A. Increased Victim Compensation}

A fundamental, underlying purpose behind both FTCA and Bivens actions is improving victim compensation. ${ }^{73}$ Yet the rate of victim recovery im Bivens actions has been extremely low, ${ }^{74}$ and constitutional violations generally fall outside the scope of the FTCA. ${ }^{75}$

The good faith immunity established in Butz poses a significant barrier to recovery froin government officials. However, the rationales for this immunity-protecting officials from hability for mistakes made in good faith ${ }^{76}$ and promoting the vigorous execution of official duties $^{77}$-are not applicable when the Governinent is the defendant. If the Government is liable for compensating the victim for a constitutional violation that stems from an official's good faith mistake, then the official will neither be treated unfairly nor be hindered from vigorously exercising her duties.

Under an equitable loss spreading and risk allocation analysis, several factors support allocating risk of loss to the Government. ${ }^{78}$

Sess. (1983) [hereinafter cited as H.R. 595 Hearings]; S. 1775 Hearings, supra note 6, pt. 1; id. pt. 2; Amendment of the Federal Tort Claims Act: Hearings on H.R. 2659 Before the Subcomm. on Ad. ministrative Law and Governmental Relations of the House Comm. on the Judiciary, 96th Cong., 1st Sess. (1979) [hereinafter cited as H.R. 2659 Hearings]; H.R. 9219 Hearings, supra note 7; Amendments to the Federal Tort Claims Act: S. 2117: Joint Hearing Before the Subcomm. on Citizens and Shareholders Rights and Remedies and the Subcomm. on Administrative Practice and Procedure of the Senate Comm. on the Judiciary, 95th Cong., 2d Sess. pt. 1 (1978) [hereinafter cited as S. 2117 Hearings].

72. See Bell, supra note 9, at 9-10; Casto, supra note 9, at 260; Madden, Allard \& Reines, supra note 10, at 478; Schuck, supra note 5, at 346; Project, supra note 33, at 1091-92; Note, supra note 5, at 697-99.

73. Nixon v. Fitzgerald, 457 U.S. 731, 783 \& nn.25-26 (1982) (White, J., dissenting); Newport v. Fact Concerts, Inc., 453 U.S. 247, 268 (1981); Carlson v. Green, 446 U.S. 14, 20 (1980) (citing S. REP. No. 93-588, 93rd Cong., 1st Sess. 3 (1973)); Schuck, supra note 5, at 285.

74. In 1981, Donald Devine, Director of the Office of Personnel Management, stated, "The Department of Justice estimates that there have been possibly 10,000 such lawsuits since 1971. Of that total, only thirteen have resulted in judgments for plaintifs." See S. 1775 Hearings, supra note 6, pt. 2, at 142.

75. See supra notes $26-28$ and accompanying text.

76. Butz v. Economou, 438 U.S. 478,497 (1978).

77. See infra notes $82-83$ and accompanying text.

78. One author has drawn the analogy between loss spreading theories in manufacturer's product habilities and governmental tort hability. The goals in the former context are (1) minimizing damages to consumers, (2) placing the burden of loss on the inanufacturer who has control over the product and can best minimize the danages, and (3) distributing the loss equitably among the consuming public as a cost of doing business. In the latter context, the goals are (1) minimizing unconstitutional acts, (2) placing the costs on the government entity which can control its employees and thereby deter unconstitutional acts, and (3) distributing the loss equitably 
First, the Government has control over its employees and can best prevent any wrongdoing by them. Second, the Government can equitably spread the costs of providing its services, including the cost of compensating injury, among the meinbers of the public, who benefit from government services. Finally, unlike federal einployees whose salaries are often too modest to satisfy judgments, the Government is able to pay coinpensation awards to victims. Thus, the risk of injury and the burden of compensation should be placed on the Government and not on the victim..$^{79}$

In Owen $v$. City of Independence, ${ }^{80}$ the Supreine Court recently embraced the view that the cost of compensating mjury should be allocated to the Government. The Court rejected a inunicipal government's attempt to raise the good faith immunity of its employees:

How "uniquely amiss" it would be . . . if the government itself"the social organ to which all in our society look for the promotion of liberty, justice, fair and equal treatment, and the setting of worthy norms and goals for social conduct"-were permitted to disavow liability for the mjury it has begotten. . . . A damages remedy against the offending party is a vital component of any scheme for vindicating constitutional guarantees [and its importance] is only accentuated when the wrongdoer is the institution that las been established to protect the very rights it has transgressed. ${ }^{81}$

\section{B. Effect upon Employee Performance}

It is argued that if the Government were the exclusive defendant,

among the public, the beneficiary of government services. Project, Suing the Police in Federal Court, 88 YALE L.J. 781, 816 n.195 (1979). Furthermore, damages awarded to successful plaintifis should be borne by "deep pocket" defendants who are better able to pay the awards. $I d$. at 817 \& n.198 (citing G. Calabresi, The Costs of Accidents 21 (student ed. 1970)).

79. See Madden, Allard \& Reines, supra note 10, at 486; Comment, Federal Tort Claims Act: Liability of the United States for Acts Committed in Good Faith by Federal Law Enforcement Officcrs, 63 MnN. L. REv. 1293, 1301-02 (1979). Mark Lynch, American Civil Liberties Union Staff Attorney, has illustrated the unjust result that can follow froin good faith immunity:

Let us suppose that . . . a policeman in a squad car sees someone commit a crime and the perpetrator takes off in his automobile. The squad car gives chase in hot pursuit and the officers, as they approach an intersection, decide that they have to run a red light. They turn on their siren and their flashing lights. A little old lady is in the intersection and she doesn't hear the sirens or see the lights, and the police car runs her over.

Now, are we to say that because those officers were pursuing the perpetrator in good faith that the little old lady shouldn't have recovery. I think that's a monstrous result. S. 1775 Hcarings, supra note 6 , pt. 1 , at 21 .

With the exception of the most recent proposals introduced during the 97th and 98th Congresses under the Reagan Administration, none of the proposals to amend the FTCA has extended the einployee's qualified immunity to the Government. Compare S. 775, 98th Cong., 1st Sess. (1983), and H.R. 7034, 97th Cong., 2d Sess. (1982), and S. 1775, 97th Cong., 1st Sess. (1981), with H.R. 24, 97th Cong., 1st Sess. (1981), and S. 695, 96th Cong., 1st Sess. (1979), and H.R. 2659, 96th Cong., 1st Sess. (1979), and S. 2117, 95th Cong., 1st Sess. (1977).

80. 445 U.S. 622 (1980).

81. Id. at 651 . 
federal employees would be relieved of the threat of personal liability and would be free to carry out their duties assertively. ${ }^{82}$ The public's strong interest in "vigorous decisionmaking" 83 stems from

the desire to encourage officials to take initiative, act decisively, and perform their jobs without constantly worrying about protecting themselves against the possibility that they will be hauled into court. We want law enforcement agents to follow up on suspicious behavior, prison guards to quell disorders, inspectors to cite violators, and supervisors to discharge or discipline incompetent or malingering employees. ${ }^{84}$

But the interest in resolute decisionmaking is not the only public interest at stake. As is argued below, ${ }^{85}$ eliminating all personal liability for federal employees would harm the public interest in deterring federal employees from committing constitutional violations. ${ }^{86}$

\section{III}

\section{The Need For InDividual AcCountability}

Congressional proposals to anend the FTCA by making the Government the sole defendant in constitutional tort actions and by providing absolute immunity for federal officials ${ }^{87}$ are sensible when an official acts in good faith. It is fair that an official not be liable for her honest and reasonable mistakes; personal liability would not deter further wrongdoing and might tend to inhibit the official from taking decisive action in the future. But lest the victim go uncompensated, it is necessary that the Government bear the costs of an employee's good faith violation.

The rationale for the good faith immunity does not extend to cases where a federal official commits a malicious or reckless violation of

82. This is a major reason for the federal Government's support for proposals to waive sovereign immunity. See Bell, supra noto 9, at 6-7; Schuck, supra note 5, at 311-15; S. 1775 Hearings, supra note 6, pt. 1, at 13 (statement of Edward C. Schmults, Deputy Att'y Gen., Department of Justice); id. pt. 1, at 153 (statement of Rod Murray, President, Federal Managers Association); id. pt. 2, at 130-33 (statement of Elliot L. Richardson, former United States Att'y Gen.); id. pt. 2, at $142-45$ (statement of Donald J. Devine, Director, Office of Personnel Management); see also Ranii, The Suits that U.S. Aides Fear, NAT'L L.J., Jan. 18, 1982, at 1, col. 4, reprinted in S. 1775 Hearings, supra note 6, pt. 1, at 45.

83. S. 1775 Hearings, supra note 6, pt. 2, at 22 (statement of Peter H. Schuck, Professor of Law, Yale Umiversity).

84. Id.

85. See infra text accompanying notes 88-101.

86. The American Bar Association recently stated: "This lack of employee accountability when the government assumes responsibility is the center of the opposition to the bili by the American Bar Association." Senate Panel Amends Tort Claims Bill, ABA Wash. Letrer, Oct. 1, 1982, at 6 (referring to S. 1775). But cf. H.R 2659 Hearings, supra note 71, at 151-54 (statement of B. James George, Jr., former Chairperson, Criminal Justice Section, on behalf of the American Bar Association explaining terms of substitutes for personal liability that would be acceptable).

87. See supra note 8. 
another's constitutional rights. The interests of victim compensation and vigorous decisionmaking may be served by making the federal Government the sole defendant in constitutional tort cases. However, eliminating all individual liability would also eliminate the deterrent to official imisconduct that personal liability provides. ${ }^{88}$ Moreover, providimg immunity for mahicious and reckless actions undermines traditional notions of personal accountability for one's actions. ${ }^{89}$ Currently officials are held accountable only for unconstitutional actions undertaken in bad faith. ${ }^{90}$ If the existimg level of accountability is further diminished, the number of constitutional violations may well imcrease. ${ }^{91}$

Implicit in the argument that absolute immunity is necessary to avoid employee harassnent and fear of liability ${ }^{92}$ are the assumptions that the current good faith standard of immunity is an imsufficient shield from liability, and that fear of liability inhibits decisive action. In fact, however, federal officials have seldoin been held liable when charges of unconstitutional conduct have been pressed against them. Of the thousands of actions filed against government employees snice 1971, only thirteen have resulted in judgments for the plaintiff. ${ }^{93}$ Thus, to the extent that fear of hability substantially inhibits federal officials from executimg their duties, such fear seems generally unfounded.

Furthermore, absolute immunity will not reheve government offi-

88. See S. 1775 Hearings, supra note 6, pt. 1, at 142-43 (statements of Thomas Devine, James Gaylord, and Louis Clark); S. 2117 Hearings, supra note 71, at 72 (letter from ACLU Director John H.F. Shattuck to Raymond S. Calamaro, Oct. 3, 1977); Bermann, Integrating Governmental and Officer Tort Liability, 77 CoLUM. L. REv, 1175, 1198-99 (1977).

"The extension of absolute immunity from damages liability to all federal executive officials would seriously erode the protection provided by basic constitutional guarantees." Butz v. Economou, 438 U.S. 478, 505 (1978); see also Intelligence Activities and the Rights of Americans, Final Report of the Select Comm. to Study Governmental Operations with Respect to Intelligence Activities, reprinted in S. 2117 Hearings, supra note 71, pt. 1, at 145-46.

89. See Complete Auto Transit, Inc. v. Reis, 451 U.S. 401, 429 (1981) (Burger, C.J., dissenting), where Justice Burger emphasized the importance of individual accountability:

Accountabililty of each individual for individual conduct hes at the core of all law-indeed, of all organized societies. The trend to eliminate or modify sovereign immunity is not an unrelated development; we have noved away from "The King can do no wrong." This principle of individual accountability is fundamental if the structure of an organized society is not to be eroded to anarchy and impotence, and it remains essential in civil as well as criminal justiee.

90. Butz v. Economou, 438 U.S. 478 (1978).

91. As the Butz Court noted:

Indeed, the greater power of such officials affords a greater potential for a regime of lawless conduct. Extensive government operations offer opportunities for unconstitutional action on a massive scale. In situations of abuse, an action for damages against the responsible official can be an important means of vindicating constitutional guarantees.

Id. at 506 .

92. See supra note 82 .

93. See supra note 74 . 
cials from entanglement in litigation. ${ }^{94}$ Even when the suit is solely agamst the Government, it will still require the official's participation for she will be involved in developing the Government's defense, participatimg in discovery, and testifying at trial. Hence, even exclusive governmental liability would not entirely eliminate the time and effort required to defend the actions. ${ }^{95}$

What the arguments for absolute immunity ignore is society's important interest in protectimg the public from governmental misconduct. When a federal employee willfully or maliciously violates another's constitutional rights, absolute immunity provides her with a deep-pocket insurer, permittimg her to disregard tlie rights of others with impunity.

The Supreme Court's reasoning in Butz v. Economou, ${ }^{96}$ as well as that of every federal circuit court that has faced the issue, ${ }^{97}$ supports the argument that personal liability for federal officials should not be eliminated altogetler. In concluding that federal officials should be afforded qualified rather than absolute immunity, the Butz Court quoted froin an 1882 Supreme Court case:

"No man in this country is so high that he is above the law. No officer of the law nnay set that law at defiance with impumity. All the officers of the government, from the highest to the lowest, are creatures of the law, and are bound to obey it." 98

Accordingly, mdividual liability serves an important propliylactic function, which, if eliminated, would force the public to rely solely on government agencies to police their own officials.

The Butz Court also stated that granting absolute immunity to all federal employees would create an unjust disparity between federal and state officials. State officials who are sued for constitutional violations under section 1983 are afforded only qualified immunity. ${ }^{99}$ The Court stated, "[F]ederal officials sliould enjoy no greater zone of protection when they violate federal constitutional rules than do state officers."100 Therefore, to "create a system in which tlee Bill of Rights inorntors more closely tlie conduct of state officials than it does federal

94. Note that the cost of such litigation is most often not borne by the employee; the Government will generally either provide counsel or pay for a private attorney to represent the defendant employee. See S. 2117 Hearings, supra note 71, pt. 1, at 90-92 (letter of Assistant Att'y Gen. Barbara Allen Babcock to Sen. Metzenbaum); id. pt. 1, at 101-03 (listing cases in which private counsel was retained).

95. See Bermann, supra note 88 , at 1195.

96. 438 U.S. 478 (1978).

97. Id. at 486; cases cited id. n.9.

98. Id. at 506 (quoting Umited States v. Lee, 106 U.S. 196, 220 (1882)).

99. See Wood v. Strickland, 420 U.S. 308, 322 (1975).

100. 438 U.S. 478,501 (1978) (emphasis in original). 
officials is to stand the constitutional design on its head." 101

Many state governments that have established tort claims acts have rejected absolute immunity for state officials. Instead they allow their officials to be held personally liable for acts committed within the scope of their employment and perpetrated either with malice or reckless disregard for the rights of others. ${ }^{102}$ In amending the FTCA, Congress should follow the lead established by the state legislatures, and provide personal liability for government officials who flagrantly abuse their power and cause injury through malicious or reckless acts.

Finally, if legislation is passed that makes the federal Government the exclusive defendant in a damage suit for constitutional violations committed by a federal official, it is unclear whether such legislation would overrule Bivens. In Carlson v. Green, the Court stated that the Bivens remedy could be replaced only by a remedy that is "equally effective." 103 Absolute immunity, coupled with the proposed substitutes of strengthened disciplinary procedures and punitive damages against the Government, are clearly less effective deterrents than individual hability. ${ }^{104}$ Thus, a court could refuse to give effect to the absolute immunity section of the statute on the ground that such legislation is less effective in protecting constitutional rights than the Bivens remedy. ${ }^{105}$ Therefore a court might permit a plaintiff to maintain an action against both the official and the United States, despite such a statute. Indeed, the Court has stated that official immunity law has "in large part been of judicial making," 106 and for this reason undue emphasis should not be placed on the "congressional origins of the cause of action in determining the level of immunity."107 The federal courts are, therefore, "equally competent to determine the appropriate level of immunity where the suit is a direct claim under the Federal Constitution against a federal official."108

101. Id, at 504 .

102. See, e.g., CAL. Gov't Code \$ 825.2(b) (West 1980); Colo. Rev. STat. \$ 24-10110(1)(a)-(b)(I), 3(b)(I) (1982); Local Governmental and Governmental Employees's Tort Immunity Act, Ill. ANN. STAT. ch. 85, $\$ \$ 2-102,-202$ (Smith-Hurd 1966), construed in Newell v. City of Elgin, 34 Ill. App. 3d 719, 722, 724-25, 340 N.E.2d 344, 348-49 (I976); MinN. STAT. ANN. \$ 3.736(9) (West Supp. 1982); N.J. Rev. STAT. § 59:3-14 (1982); N.Y. PuB. OfF. LAW § 17(3)(a) (McKinney Supp. 1982); Tex Rev. Crv. STAt. ANN. art. 6252-26 \& 1 (Vernon 1979 \& Supp. 1982).

103. 446 U.S. 14, 18-19 (1980).

104. For a discussion of the problems associated with these proposals, see infra text accompanying notes 111-32.

105. See Carlson v. Green, 446 U.S. 14, 21 (1980) ("Because the Bivens remedy is recoverable against individuals, it is . . . almost axiomatic that the threat of damages has a deterrent effect, surely particularly so when the individual official faces personal financial liability.") (citations omitted); see also id. at 21 n.6 (\$1983 serves similar purposes); Butz v. Economou, 438 U.S. 478, 505 (1978).

106. 438 U.S. at 501-02 (quoting Barr v. Mateo, 360 U.S. 546, 569 (1959)).

107. Id. at 501 .

108. Id. at 503. But $c f$. Bush v. Lucas, 103 S. Ct. 2404 (1983) (In a strong policy area, an 


\section{IV}

\section{The Feasibility of Proposed Substitutes for the DeterRence and AcCountability Provided BY INDIVIDUAL LIABILITY}

Proposals to totally immunize government officials from civil liability are based on the expectation that other avenues will remain available to deter wrongdoing and ensure imdividual accountability. Substitutes for personal liability that liave been suggested include loolding officials responsible through criminal or administrative disciplinary proceedings, and assessing punitive dainages against the Government.

\section{A. Plaintiff-Participatory Disciplinary Procedures}

By the late 1970's the Justice Departınent and a variety of public interest organizations agreed that neither criminal sanctions nor existing agency disciplinary procedures could, by themselves, ensure deterrence or accountability. ${ }^{109}$ This conclusion seems well founded. ${ }^{110}$ For example, in 1976 the Departinent of Justice provided a Senate subcommittee with the information that during the previous ten years, criminal cliarges liad been filed against only five federal einployees for conduct that violated another's civil rights. ${ }^{111}$ Likewise, the results of internal agency disciplinary proceedings have been no better. In 1979 the Department of Justice informed FBI Director Williain Webster that it had evidence of thirty-two illegal entries, seventeen unauthorized wiretaps, and numerous illegal mail openings implicating sixtyeight FBI employees. Disciplinary action was found appropriate for only six employees and only mild sanctions were applied. ${ }^{112}$

elaborate statutory scheine for redressing constitutional injuries can constitute a special factor counselling against creation of a Bivens remedy.).

109. During early discussions of proposed FTCA amendinents, civil liberty and public interest organizations expressed concern that exclusive governmental liability would eliminate deterrence of unconstitutional activity. See Bell, supra note 9, at 11-12; S. 2117 Hearings, supra note 71 , pt. 1, at 70-79.

110. Widespread violations of individuals' constitutional rights by the FBI's COINTELPRO program and the CIA's Operation CHAOS were documented by the Senate Intelligence Committee in 1975. These prograins are only two examples of extensive government operations that abuse citizens' rights. See Boger, Gitenstein \& Verkuil, supra note 70, at 499 n.6.

111. S. 2117 Hearings, supra note 71, pt. 1, at 20-21. Even wherc the Department of Justice has prosecuted and received convictions for civil rights violations, the Government has extended itself to shield the individuals froin punishment. For example, W. Mark Felt, former Acting Associate Director of the FBI, and Edward Miller, former Assistant Director for the Dounestic lntelligence Division, were convicted in United States District Court of conspiring against the rights of citizens. On March 26, 1981, they were given a full and unconditional pardon by President Reagan. Gray v. Bell, 542 F. Supp. 927,929 (D.D.C. 1982).

112. H.R. 2659 Hearings, supra note 71, at 45 (statement of Karen Christensen, Legislative Counsel, American Civil Liberties Union); accord Carlson v. Green, 446 U.S. 14, 21 \& n.8 (1980), where the Supreine Court acknowledged the doubt cast on the adequacy of existing disciplinary inechanisins for federal einployees who violate constitutional rights. 
Because agency discipline is typically not subject to outside review, ${ }^{113}$ it is of questionable value as a deterrent. As one Senate subcommittee concluded, "[A]gencies have disciplined their employees for constitutional torts only after being subjected to intense outside pressure to do so."114 Given the inherent interest of government agencies in protecting their einployees from liability, legislators have recognized that existing disciplinary procedures must be inade subject to outside scrutiny if they are to be effective. For example, bills introduced by the Departinent of Justice under the Carter Administration proposed that an aggrieved party be permitted to initiate and participate in agency disciplinary proceedings, and have the right to appeal decisions of the disciplinary board in federal district court should the aggrieved party believe that the sanctions iniposed by the agency were madequate. ${ }^{115}$

There are several drawbacks to the proposed disciplinary inechamisms. First, no consensus exists as to what procedural rights plaimtiffs and employees should have in such proceedings, what degree of discretion should be permitted the agencies in determining the rights of the parties, and what the structure of the appeals process should be. ${ }^{116}$ Moreover, there is no way to ensure that any one schenne for reviewing alleged violations of constitutional rights would work for all federal agencies, making it likely that a person's ability to vimdicate her constitutional rights would depend on which federal agency employed the offending official. ${ }^{117}$

A more significant problem with plaintiff-participatory disciplinary proceedings is that the burden of initiating these proceedings inay fall on the injured individual. Because a disciplinary proceeding is likely to be tinue-consuming and expensive, a person may be unwilling or unable to initiate one without financial assistance. Moreover, simce

113. See S. 1775 Hearings, supra note 6, pt. 2, at 4-7 (testimony of FBI Director William Webster explaining the centralized nature of the FBI's disciplinary procedure); Bell, supra note 9, at 12 \& n.42 (statement of former United States Att'y Gen. Griffin Bell that "agency discipline is conducted behind closed doors").

114. S. 2117 Hearings, supra note 71, pt. 2, at 839.

115. H.R. 2659, 96th Cong., 1st Sess. (1979); S. 695, 96th Cong., 1st Sess. (1979); S. 3314, 95th Cong., 2d Sess. (1978). These proposed disciplinary proceedings were not retained in bills introduced in the 97th and 98th Congresses. See H.R. 595, 98th Cong., 1st Sess. (1983); S. 1775, 97th Cong., 1st Sess. (1981); H.R. 24, 97th Cong., 1st Sess. (1981).

116. H.R. 2659 Hearings, supra note 7I, at 44-46 (statement of Karen Christensen, Legislative Counsel, American Civil Liberties Union); id. at 30-31 (stateinent of Vincent L. Coimery, National President, Mational Treasury Employees Union); id. at 57-58 (statenent of Nancy Drabble, Staff Attorney, Congress Watch); id. at 70-71, 73 (summary of testimony of the Fund for Constitutional Government on Proposed Amendinents to the Federal Tort Claims Act); id. at 88-89 (statement of Ordway P. Burden, President, Law Enforcement Assistance Foundation); id. at 122-26 (statement of George A. Bermann, Professor of Law, Columbia University School of Law).

117. For example, the FBI and the CIA may require closed proceedings due to the confidential nature of their operations, whereas other agencies whose operations are less sensitive should have open proceedings. 
the plaintiff would also have to bring a civil action against the federal Government to gain compensation for her injury, many individuals may choose not to take on the added burden of initiating agency disciplinary proceedings.

In addition, these proposed disciplinary proceedings may disrupt agency operations and lower employee morale while doing little to deter misconduct. It is awkward and disruptive for an outside person to mitiate an agency proceeding against an employee for an action often taken under the agency's authority. ${ }^{118}$ At the sane time the plaintiff is likely to encounter resistance from the agency ${ }^{119}$ in the course of such proceedings. Finally, in view of the inherent conflict of interest that exists when an agency must discipline its own employees, it is unlikely that victim participation will substantially increase the deterrent value of agency disciplinary proceedings. ${ }^{120}$

While disciplinary proceedings with public access are by themselves imadequate protection froin official inisconduct, they are a positive step toward improving employee accountability. Given the public interest in individual accountability for federal officials, it is appropriate that a revision of the FTCA imclude ineasures that improve public access to infornation concerning constitutional violations. Recent congressional proposals included provisions which would have required that whenever a judgment was paid by the United States, the Attorney General would notify the department or agency so that it might institute sucl further investigation and disciplinary action "as may be appropriate."121 In addition to such a provision, Congress should amend the FTCA to require that each agency or department file a yearly report with the Office of Perso1mel Management and the Merit Systems Protection Board stating: (1) the number of FTCA actions filed, dismissed, settled, and finally adjudicated, and (2) each case in which

118. Richard K. Pelz, President-Elect of the Federal Executive and Professional Association, stated that "an abuse of authority by an individual often is not an isolated event but is part of an agency practice." Tort Claims, Hearings on H.R. 24, H.R. 3060, and H.R. 3799 Before the Sub. comm. on Administrative Law and Governmental Relations of the House Comm. on the Judiclary, 97th Cong., 1st \& 2d Sess. 331 (1982).

119. See, e.g., H.R. 2659 Hearings, supra note 6, at 126 (testimony of Professor George A. Bermann, Columbia University School of Law).

Thoinas Madden, Nicholas Allard, and David Renes discuss an indcpendent disciplinary body that could avoid the conflict of interest and questionable impartiality of agency proceedings. They state that such a body should not replace or duplicate existing administrative disciplinary proceedings, and that discipline should reinain in the first instance with the employing agency. Madden, Allard \& Remes, supra note 10, at 487-89. Without details on how this independent body would fimction and clarification on its role vis-a-vis existing agency proceedings, it is diffcult to predict its feasibility as a substitute for personal hability.

120. In fact, such proceedings generally have not proven to be effective in deterring official misconduct. See Bermann, supra note 88, at 1198 \& n.138.

121. H.R. 7034, 97th Cong., 1st Sess. § 202 (1982) (proposed 28 U.S.C. \& 2700); S. 1775, 97th Cong., 1st. Sess. § 5(c) (1981). 
damages were awarded, specifying what investigation was conducted, the results of the investigation, and what disciplinary action was taken, if any. Any case in which punitive damages were awarded should be referred to the Criminal Division of the Justice Department, which would then determine whether to file criminal charges.

\section{B. Punitive Damages Against the Government}

Bills providing a right to punitive danrages against the United States for the unconstitutional actions of its employees were introduced in Congress in 1982 and 1983. ${ }^{122}$ These bills provide an exclusive reinedy against the United States for constitutional violations committed by federal eniployees acting within the scope of their einploynent. For example, one such bill provided that if "the conduct giving rise to the tort claim was undertaken with the malicious intention to cause a deprivation of constitutional rights or with reckless disregard for the plaintiff's constitutional rights, the court shall award, in addition, damages of not more than $\$ 100,000 . " 123$

The purpose of punitive damages is to punish the defendant and to deter her and others froin future wrongdoing. They are given when there are aggravating circumstances beyond the mere commission of a tort that create a sense of moral outrage-circumstances evidencing malice, willfulness, or recklessness. ${ }^{124}$ One rationale for allowing punitive damage awards against the Government is that if the Government is forced to pay large damage awards, it will respond by promulgating clear standards of acceptable employee behavior and applying disciplinary procedures to enforce these standards. ${ }^{125}$

122. H.R. 595, 98th Cong., 1st Sess. (1983); H.R. 7034, 97th Cong., 2d Sess. (1982).

123. H.R. 7034, 97th Cong., 2d Sess. $\$ 202$ (1982) (proposed 28 U.S.C. $\$ 2593$ ). H.R. 7034 was reintroduced as H.R. 595, 98th Cong., 2d Sess. (1983). There is an apparent contradiction in the bill in that $\S 202$ also states that the Uinted States sliall not be liable for punitive dmages.

Aside froin those few recent bills that allow punitive or exemplary damages, see supra note 122, inost of the proposals have called only for an award of actual damages or liquidated damages of $\$ 1,000$, whichever is greater, see, e.g., S. 1775, 97 th Cong., 1st Sess. $\$ 3$ (1981) (proposed 28 U.S.C. $\$ 2674(b)(2))$. The amount was raised to $\$ 2,000$ in the House bill proposed in the 98 th Congress. See, e.g., H.R. 595, 98th Cong., 1st Sess. § 202 (1983) (proposed 28 U.S.C. § 2693). The nature of inost constitutional injuries makes actual damages difficult if not impossible to ineasure. Thus, most plaintiffs will be left with statutory liquidated damages. See Yudof, Liability for Constitutional Torts and the Risk-A verse Public School Official, 49 S. CAL. L. REV. 1322, 1375 (1976); Note, Damage Awards for Constitutional Torts: A Reconsideration After Carey v. Piphus, 93 HaRv. L. REV. 966, 988 (1980).

124. W. Prosser, HandBook on the LaW of Torts $\$ 2$, at 9-14 (4th ed. 1971); D. DobBs, HANDBOOK ON THE LAW OF REMEDIES \& 3.9, at 204-08 (1973).

125. See $S$. 1775 Hearings, supra note 6, pt. 1, at 248 (statement by the Federal Executive and Professional Association); Title 13 of S. 829-To Amend the Federal Tort Claims Act: Hearings Before the Subcomm. on Administrative Practice and Procedure of the Senate Comm. on the Judiciary, 98th Cong., 1st Sess. 125-26 (1983) (statement of Jerry Berman, Legislative Counsel, American Civil Liberties Union). One proponent has argued that punitive damage awards agaimst the 
There are, however, three significant arguments agamst permittimg punitive damages to be recovered from the federal Government. First, a punitive damage award agamst the Government is an madequate substitute for the more direct deterrence and accountability provided by individual liability. The Government may often be willing to absorb the added costs of litigation and damage claims rather than take the steps necessary to prevent future violations, particularly if the awards are paid out of general treasury funds rather than the budget of mdividual agencies. ${ }^{126}$

Second, the concept of deterrence seems mapplicable to a large government entity. This reasoning was followed in Edmonds v. Dillin, ${ }^{127}$ where the court demed the plaintiff's request for pumitive damages against a municipal government. The court explamed that a pumitive damages award agamst the Government does not serve the goal of deterrence:

With respect to deterrence, a municipality, unlike an individual, is not a monolithic entity; it does not act witl a single mind or motive. Its policies are an amalgam of past acts by various actors. Therefore, the concept of achieving deterrence, as it is traditionally conceived, is less applicable in the case of a municipality than an individual. ${ }^{128}$

A third major difficulty with allowing pumitive awards agamst the Government is, as the Edmonds court recognized, that such awards operate to the detriment only of the taxpayers. ${ }^{129}$ Unlike a compensatory remedy, which spreads the cost of "mistakes" in government operations among the taxpayers who benefit from government services, pumitive damages agamst the Government simply impose the cost of one imdividual's reprehensible behavior directly on society. This seems unfair. The Supreme Court endorsed this view in City of Newport v. Fact Concerts, Inc. ${ }^{130}$ by refusing to hold municipalities liable for punitive damages under section 1983. Similarly, many state tort claims acts specifically exempt state governments from punitive or exemplary damages. ${ }^{131}$

Government would have a deterrent effect because "[p]otential great liabililty will make the conscientious official in command more vigilant to prevent and report tortious, unconstitutional acts by his fellows and subordinates to protect the federal Treasury and the budget of his agency." H.R. 2659 Hearings, supra note 71, at 72 (testimony of William Dobrovir, Counsel, Fund for Constitutional Government).

126. See Boger, Gitenstein \& Verkuil, supra note 70, at 542; S. 1775 Hearings, supra note 6, pt. 2, at 25 (testimony of Professor Peter Schuck, Yale Law School).

127. 485 F. Supp. 722 (N.D. Ohio 1980).

128. Id. at 730 .

129. $I d$.

130. 453 U.S. 247,267 (1981).

131. Cal. Gov't Code $\$ 818$ (West 1980); Colo. Rev. Stat. \$ 24-10-110 (4) (1982); Local Governmental and Governmental Employees Tort Immunity Act, ILL. ANN. STAT. ch. 85, \& 2-102 (Smith-Hurd 1966); MnN. Stat. ANN. § 3.736 Subd. 3 (West 1977 \& Supp. 1983); N.J. STAT. 
There is a distinction, however, between actions motivated by an individual's malice or recklessness and actions taken as part of a regular agency practice or policy that is itself malicious or reckless, or encourages such behavior. Where the agency has a policy or practice that proinotes egregious violations, an assessment of punitive damages seems justified. Using the rationale of the Dillin court that the Government's policies are often "an amalgam of past acts by various actors," 132 clearly the entity itself can at times be wrong. In this imstance, assessing punitive dainages against the Government would encourage a change in policy and thereby deter wrongdoing. The removal of policies or practices that cause repeated and egregious mjuries is certainly a benefit to the public, and well worth the cost.

\section{$\mathrm{V}$ \\ Proposal to AMEND the FTCA}

It is possible to annend the FTCA in a maimer that would accommodate the competing concerns of shielding federal officials from vexatious litigation, protecting the public by deterring official misconduct, and compensating victims for the deprivation of their constitutional rights. ${ }^{133}$ First, the FTCA should be amended to waive sovereign immumity to suits against the Government for damages resulting from constitutional violations committed by government employees. Second, to protect federal employees froin frivolous or harassing suits, the FTCA should codify the Harlow test, which requires that the plaintiff in a constitutional tort case ineet a strict, objective standard in order to avoid disumssal or summary judgment in favor of the employee. Third,

ANN. § 59:9-2(c) (West 1982); Tex. Rev. Civ. Stat. ANN. art. 6252-19 § 3 (Vernon 1970 \& Supp. 1982).

132. Edmonds v. Dillin, 485 F. Supp. 722, 730 (N.D. Ohio 1980).

133. A proposal similar to that suggested below was introduced in Congress in 1982 by Senators Arlen Specter (R-Pa.) and Mac Baucus (D-Mont.), and was accepted as an amendment to S. 1775 by the Senate Judiciary Subcommittee on Agency Administration in late 1982. Mark-up of S. 1775: Transcript of Proceedings Before the Subcomm on Agency Admininstration of the Senate Comm. on the Judiciary, 97th Cong., 2d Sess. (Sept. 23, 1983) (on file with the California Law Review). The amendment was not remtroduced in 1983 when S. 1775 was reintroduced as S. 775.

Under the "Specter Amendment," the Government was to be solely liable for compensatory damages. Government officials were to be liable for punitive damages upon a finding that the official violated another's constitutional rights. The Government was to be jointly liable for up to $\$ 50,000$ of punitive damages, for which it could seek recovery from the official. The amendment also contamed some procedural provisions designed to protect against frivolous or insubstantial claims.

The Specter Amendment differs from the proposal advanced in this Comment in several respects. First, it allows punitive damages to be awarded against the Government regardless of whether the wrong was part of a governmental or individual practice. Second, it imposes a high risk on plamtiffs by allowing a court to award attorney's fees and expenses for failure to state a claim, not just for bad faith claims. Finally, no pumitive damages are available against an official for reckless violations of constitutional rights - only for willful and malicious violations. 
when a defendant employee is not dismissed from the action and the court finds the employee knew or should have known she was violating an individual's constitutional rights or that the official acted out of malice or recklessness, the Government should be given a right of pro rata contribution from employee defendants for compensatory damages. The employee should be solely hable for any punitive damages awarded unless the action was taken as part of an agency policy or widespread practice. In that case the court should have discretion to assess punitive damages against both the Government and the official if appropriate. Because this proposal would retaim the qualified immumity for officials and would waive sovereign immunity for the Government, the result would be that where an employee acted im good faith, the Government would be solely liable.

\section{A. Exclusive Governmental Liability for Good Faith Violations}

The Government should be the exclusive defendant in constitutional tort actions when the employee acted in good faith. This would protect employees by limiting a full trial to only those cases im which an official cannot produce enough proof to support her motion to dismiss or for summary judgment. Making the Government the defendant aids effective governmental services by maintaining substantial employee protections and at the same time provides victims with an adequate source of compensation.

Acceptance of this proposal undoubtedly would depend largely on whether official liability can be limited so that claims of malice or recklessness are litigated only where there is substantial evidence of such mtent. The mability to summarily dismiss frivolous or insubstantial suits has been a key factor im the innetus toward the elimination of mdividual liability altogether. ${ }^{134}$ Yet, through use of the objective Harlow standard ${ }^{135}$ for sumınary judgment, litigation of frivolous claims should be extremely rare. A review of cases applying the Harlow test clearly indicates that government employees are not havmg difficulty obtaining dismissals and summary judgment. ${ }^{136}$ If Con-

134. See Bell, supra note 9, at 7; Schuck, supra note 5, at 320-30, 345-61.

135. 457 U.S. 800 (1982).

136. A Lexis search conducted on September 9, 1983, revealed that of the 81 reported cases actually decided under the Harlow standard, 48 resulted in dismissal or a grant of summary judgment for the defendants. In 19 the conrt found that the defendants violated clearly established law and immunity was inappropriate. In only 14 of the cases did the court refuse to dismiss or grant summary judgment because of factual issues.

The following cases resulted in dismissal or summary judgment for the defendants: Stuebig v. Hammel, 714 F.2d 292, 293 (3d Cir. 1983) (per curiam); Sellers v. United States, 709 F.2d 1469, 1471 (11th Cir. 1983) (per curiam); Egger v. Phillips, 710 F.2d 292, 314-15 (7th Cir. 1983); Johnson v. Brelje, 701 F.2d 1201, 1210 (7th Cir. 1983); Silverman v. Ballantine, 694 F.2d 1091, 1091 (7th Cir. 1982); Sampson v. Kimg, 693 F.2d 566, 569-70 (5th Cir. 1982); Green v. White, 693 F.2d 


\section{gress believes that the Harlow standard of good faith immunity does}

45, 47-48 (8th Cir. 1982); Ward v. Johnson, 690 F.2d 1098, 1110-12 (4th Cir. 1982) (en banc); Saldana v. Garza, 684 F.2d 1159 (5th Cir. 1982); Morgan v. Mansfield, 569 F. Supp. 710, 715-16 (D. Colo. 1983); Richards v. Mileski, 567 F. Supp. 1391, 1398-400 (D.D.C. 1983); Engblom v. Carey, No. 79 Civ. 4785 (S.D.N.Y. July 15, 1983); Deary v. Evans, No. Civ. 1981/26 (D.V.I. July 6, 1983); Cotner v. Sharp, 567 F. Supp. 888, $891-92$ (W.D. Okla. 1983); Jensen v. Conrad, No. 822059-14 (D.S.C. Juue 16 and Aug. 24, 1983); Dandridge v. Police Dep't of Richmond, 566 F. Supp. 152, 161 (E.D. Va. 1983); Jensen v. Conrad, No. 82-2061-15 (D.S.C. Mar. 4, 1983); St. Paul Intertribal Hous. Bd. v. Reynolds, 564 F. Supp. 1408, 1415 (D. Minn. 1983); Eliason Corp. v. Bureau of Safety \& Regulation, 564 F. Supp. 1298, 1306 (W.D. Mich. 1983); Hanlon v. Munson, No. 82-CV-779 (N.D.N.Y. May 5, 1983); Thomas v. Dugan, No. 81-474 (W.D. Pa. Feb. 28, 1983); Maldonado v. Luther, No. 80 C 2695 (N.D. Ill. Dec. 21, 1982); Weinstein v. Mueller, 563 F. Supp. 923, 931 (N.D. Cal. 1982); Dykes v. Weinberg, 564 F. Supp. 536, 543 (M.D. Fla. 1983); Coles v. Levine, 561 F. Supp. 146, 148-49 (D. Md. 1983); Spilman v. Crebo, 561 F. Supp. 652, 655-56 (D. Mont. 1982); Killarney v. Laperla, 559 F. Supp. 499, 502-03 (E.D.N.Y. 1983); Roman v. Appleby, 558 F. Supp. 449, $455-57$ (E.D. Pa. 1983) (alternative holding); Ross v. United States Postal Serv., 556 F. Supp. 729, 735 (N.D. Ala. 1983); Sanders v. Ajir, 555 F. Supp. 240, 246-47 (W.D. Wis. 1983); Piccollela v. Rieck, 555 F. Supp. 27, $27-28$ (S.D.N.Y. 1982); Flores v. Edinburg Consol. Indep. School Dist., 554 F. Supp. 974, 983-84 (S.D. Tex. 1983); Heslip v. Lobbs, 554 F. Supp. 694, 702 (E.D. Ark. 1982); Dale v. Bartels, 552 F. Supp. 1253, 1263-66 (S.D.N.Y. 1982) (alternative holdings); Dick v. Watonwan County, 551 F. Supp. 983, 996 (D. Minn. 1982) (summary judgment for solne defendants but not for others because of factual issues); Vickers v. Veterans Admin., 549 F. Supp. 85, 86 (W.D. Wash. 1982); Chocallo v. Bnreau of Hearings \& Appeals, SSA, 548 F. Supp. 1349, 1366-68 (E.D. Pa. 1982); Druckenmiller v. United States, 548 F. Supp. 193, 194-95 (E.D. Pa.), aff'd on reh'g, 553 F. Supp. 917 (E.D. Pa. 1982); Krzyske v. Commissioner, 548 F. Supp. 101, 103-04 (E.D. Micl. 1982); Huebschen v. Department of Health \& Soc. Serv., 547 F. Supp. 1168, 1177,1178 n.17 (W.D. Wis.1982) (JNOV for defendants based on Harlow; good faith issue was not clearly raised at trial); Peltack v. Borough of Manville, 547 F. Supp. 770, 775-76 (D.N.J. 1982); Souders v. Kroboth, 547 F. Supp. 187, 189-90 (E.D. Pa. 1982); Smith-Bey v. District of Columbia, 546 F. Supp. 813, 814-15 (D.D.C. 1982); Donohoe v. Watt, 546 F. Supp. 753, 756-57 (D.D.C. 1982); Albers v. Whitley, 546 F. Supp. 726, 735-37 (D. Or. 1982) (directed verdict for defendants) (alternative holdings); Standridge v. City of Seaside, 545 F. Supp. 1195, 1198-99 (N.D. Cal. 1982); Irshad v. Spann, 543 F. Supp. 922,929 (E.D. Va. 1982); Via v. City of Richmond, 543 F. Supp. 382, 385 n.1 (E.D. Va. 1982) (Harlow persuasive in summary judgment for defendants).

In the following cases the defendants violated clearly establislred law: National Black Police Ass'n v. Velde, 712 F.2d 569 (D.C. Cir. 1983); Barnett v. Housing Auth., 707 F.2d 1571, 1582-83 (1 lth Cir. 1983); Stern v. Shouldice, 706 F.2d 742, 749 (6th Cir. 1983); Miller v. City of Mission, 705 F.2d 368, 375 n.6 (10th Cir. 1983); Fujiwara v. Clark, 703 F.2d 357, 360-62 (9th Cir. 1983); Affiliated Capital Corp. v. City of Houston, 700 F.2d 226, 237 (5th Cir. 1983); Berdin v. Duggan, 701 F.2d 909, 913 (11th Cir. 1983); Clemente v. United States, 568 F. Supp. 1150, 1170 (C.D. Cal. 1983); Boussom v. City of Elkhart, 567 F. Supp. 1382, 1388-89 (N.D. Ind. 1983); Ingenito v. Department of Corrections, 568 F. Supp. 946, 950-55 (D.N.J. 1983); Bishop v. Commodity Exclrange, 564 F. Supp. 1557, 1565 (S.D.N.Y. 1983); Lightner v. Tremont Auto Auction, 564 F. Supp. 1112, 1119-20 (N.D. Ill. 1983); Dyson v. Kocik, 564 F. Supp. 109, 118-19 (M.D. Pa. 1983); Dehorty v. New Castle County Council, 560 F. Supp. 889, 892-94 (D. Del. 1983); Dennison v. Vietch, 560 F. Supp. 435, 442 (D. Minn. 1983); Lowe v. Carter, 554 F. Supp. 831, 836-37 (E.D. Mich. 1982); Benford v. American Broadcasting Cos., 554 F. Supp. 145, 150-56 (D. Md. 1982); Rhode Island Affiliate ACLU, Inc. v. Rhode Island Lottery Comm., 553 F. Supp. 752, 771 (D.R.I. 1982); Forsyth v. Kleindienst, 551 F. Supp. 1247, 1261 (E.D. Pa. 1982).

In the following cases factual questions precluded dismissal or summary judgment: Roy v. City of Augusta, 712 F.2d 1517, 1524 (1st Cir. 1983); Ellsberg v. Mitchell, 709 F.2d 51. 68-70 (D.C. Cir. 1983); McSurely v. McClellan, 697 F.2d 309, 324-25 (D.C. Cir. 1982); Douglas v. Galloway, 568 F. Supp. 966, 969-71 (S.D.W. Va. 1983); Evans v. Headley, 566 F. Supp. 1133, 1139 (S.D.N.Y. 1983); Wilkinson v. School Board, 566 F. Supp. 766, 771-72 (E.D. Va. 1983); Muzychka v. Tyler, 563 F. Supp. 1061, 1064-66 (E.D. Pa. 1983); Gannon v. Daley, 561 F. Supp. 1377, 1387-88 (N.D. 
not protect officials sufficiently, it could further deter harassing or frivolous claims by allowing a court to award reasonable attorney's fees and expenses to the defendant if the court determines that the plaintiff brought the claim in bad faith. ${ }^{137}$

\section{B. Liability for Malicious and Reckless Constitutional Violations}

When an employee acts out of mahce or recklessness and injures an individual, she should be held personally accountable. In such cases, the Government should have a right of pro rata contribution ${ }^{138}$ against the einployee for any compensatory dainages awarded. The Government should not be entitled to complete reimbursement from the employee, because it should not be relieved of all accountability for its employees' acts, which it has certified to be within the "scope of employinent." 139

Punitive damages for egregious violations of constitutional rights, which are already allowed under Bivens and in section 1983 actions, should be included in any revision of the FTCA. ${ }^{140}$ Under current proposals to make the Government a defendant in constitutional actions, damages would be limited to actual damages or $\$ 2,000$ liquidated dainages whrere actual dainages could not be proven. ${ }^{141}$ Given the difficulty of proving actual damages for a constitutional tort, many successful plaintiffs inay be limited to the $\$ 2,000$ recovery. ${ }^{142}$ Such limited damages cannot deter malicious conduct, much less redress the sense of

Ill. 1983); Woods v. Aldworth, 561 F. Supp. 891, 894-95 (N.D. Ill. 1983); Gladden v. Barry, 558 F. Supp. 676, 678-79 (D.D.C. 1983); Dick v. Watonwan County, 551 F. Supp. 983, 996 (D. Minn. 1982) (summary judgment for some defendants, but not for others because of factual issues); Anderson v. Central Point School Dist. No. 6, 554 F. Supp. 600, 607-08 (D. Or. 1982); Anderson v. New York State Div. of Parole, 546 F. Supp. 816, 825-26 (S.D.N.Y. 1982); Nakao v. Rushen, 545 F. Supp. 1091, 1092-93 (N.D. Cal. 1982).

137. See Colo. Rev. STAT. $\$ 24-10-110(5)$ (1982) (providing that attorney's fees may be awarded against the plaintiff where the court finds the allegations of malice or wanton conduct were frivolous).

138. W. Prosser, supra note $124, \S 50$, at 310 .

139. Under proposed amendments to the FTCA, suits against the Government would only be allowed when the attorney general certified that the employee was acting within the scope of her office or employment. See, e.g., H.R. 595, 98th Cong., 1st Sess. $\$ 202$ (1983) (proposed 28 U.S.C. $\$ 2699(\mathrm{~d})(1))$. The current FTCA also requires that employee actions be within the scope of employment. 28 U.S.C. \& 1346 (b) (1976).

140. For examples of malicious or reckless violations of constitutional rights where punitive damages were awarded in $\S 1983$ and Bivens actions, see Smith v. Wade, 51 U.S.L.W. 4407, 4414 (U.S. Apr. 20, 1983); Gagnon v. Ball, 696 F.2d 17, 21 (2d Cir. 1982); Busche v. Burkee, 649 F.2d 509, 520 (7th Cir.), cert. denied, 454 U.S. 897 (1981); Harris v. Harvey, 605 F.2d 330, 340-41 (7th Cir. 1979), cert. denied, 445 U.S. 938 (1980); Fielder v. Bosshard, 590 F.2d 105, 110-11 (5th Cir. 1979); Vetters v. Berry, 575 F.2d 90, 96-97 (6th Cir. 1978); Zarcone v. Perry, 572 F.2d 52, $56-57$ (2d Cir. 1978); O'Connor v. Keller, 510 F. Supp. 1359, 1375 (D. Md. 1981); Vargas v. Correa, 416 F. Supp. 266, 272 (S.D.N.Y. 1976).

141. H.R. 595, 98th Cong., 1st Sess. \& 202 (1983) (proposed 28 U.S.C. § 2693).

142. See Yudof, supra note 123, at 1375. 
moral outrage caused by egregious violations. Therefore, punitive damages should be allowed under the FTCA. They should be recoverable solely from the employee where the action was not part of a widespread agency policy or practice.

\section{CONCLUSION}

Protecting individuals from abuses of governmental power, compensatimg them for mjury resulting from such abuse, and protecting employees from liability for their good faith mistakes are miportant competing interests in a system for redress of constitutional injuries. The tension among these interests has created probleins for the executive branch, Congress, and the courts.

Until now the courts have been the most successful in reaching an admittedly uneasy accommodation of the competing interests in damage suits. The recent change im official immunity law under Harlow is important because it affords an opportunity to retain individual liability and the accountability it provides without weakening public protection. What the courts cannot do is waive sovereign immunity to improve victim compensation.

Clearly, Congress must act, but the trend toward absolute immunity for federal officials does not reflect a reasoned balance of the conlpeting interests involved. Absolute immunity is contrary to federal case law, state tort claims acts, and Congress' establishment of liability for state officials under section 1983. Absolute immunity for federal officials is an extreme and unwarranted cliange in the traditional notions of mdividual accountability.

Janell M. Byrd*

* B.A. 1980, The American University; J.D. 1983, Boalt Hall School of Law, University of California, Berkeley. 